\title{
A CONCILIAÇÃO BANCÁRIA E SUAS RELEVANTES IMPORTÂNCIAS PARA INSTITUIÇÕES PRIVADAS E PÚBLICAS- REVISÃO DE LITERATURA
}

\author{
Suélym Cristina Cabral ${ }^{1}$ \\ Ingrid Solange Sepúlveda Muñoz ${ }^{2}$
}

Resumo: Argumentar sobre conciliação bancária é altamente relevante tanto para organizações privadas como para instituições públicas, visto que é um método de controle eficiente para o atual mundo dos negócios. O objetivo dessa revisão de literatura é conceder valorização e conhecimento necessário para conciliação bancária. Com aplicação criteriosa da Ciência Contábil e o aprofundamento em diversas bibliografias, foram direcionados inúmeros fatores a serem aperfeiçoados, os mesmos foram revisados e transmitidos a áreas específicas que realizam a todo o momento o controle e o gerenciamento financeiro. Para tal foram levantados estudos dos últimos dez anos, e a constatação evidente é que a falta de conhecimento técnico e de controle conduz as empresas e instituições a desorientação e ao retrabalho. Cerca de cinquenta por cento dos artigos encontrados, relataram a grande necessidade de técnicas contábeis de conciliação bancária para tornar a gestão qualificada e a mesma garantir retorno ágil eficaz e seguro para a tomada de decisão.

Palavras-chave: Conciliação bancária; Controle; Gestão; Inovação.

\footnotetext{
${ }^{1}$ Ciências Contábeis/Centro Universitário - UNIFACVEST, Brasil. E-mail: suelymscc@hotmail.com.

2 Ciências Contábeis/Centro Universitário - UNIFACVEST, Brasil. E-mail: professoraingrid2009@hotmail.com.
} 